University of Nebraska - Lincoln

DigitalCommons@University of Nebraska - Lincoln

$4-22-2020$

\title{
Assumptions (Mistakes) that Parents Make with Estate Plans
}

\author{
Allan Vyhnalek \\ University of Nebraska-Lincoln, avyhnalek@unl.edu
}

Follow this and additional works at: https://digitalcommons.unl.edu/ageconfarmmgmt

Part of the Agribusiness Commons, Entrepreneurial and Small Business Operations Commons, Estates and Trusts Commons, Management Information Systems Commons, Other Business Commons, and the Other Economics Commons

Vyhnalek, Allan, "Assumptions (Mistakes) that Parents Make with Estate Plans" (2020). Extension Farm and Ranch Management. 29.

https://digitalcommons.unl.edu/ageconfarmmgmt/29

This News Article is brought to you for free and open access by the Agricultural Economics Department at DigitalCommons@University of Nebraska - Lincoln. It has been accepted for inclusion in Extension Farm and Ranch Management by an authorized administrator of DigitalCommons@University of Nebraska - Lincoln. 


\title{
Assumptions (Mistakes) that Parents Make with Estate Plans
}

\author{
By Allan Vyhnalek
}

April 22, 2020

The main goal of many parents when writing their estate plan is for their children to continue to be a harmonious family. With this goal in mind, parents make many assumptions to "keep the peace" when planning their estate. If the family has a key fight then family activities, like holiday gatherings, no longer happen. Let's look at these assumptions and make some observations about each. The overall goal is to think through our actions with the intent that the family stays together.

In some cases, parents say, "I don't need an estate plan. My children can do as they like with the assets." Without an estate plan, the assets are divided according to the law of the state of Nebraska. That means that you die "intestate." Intestate laws provide a hierarchy of who receives your assets (after all debt and taxes are paid) based on their relation to you. For some, dividing your assets according to intestate laws may be perfectly fine. But for those who have several heirs, these allocations can be complicated. Be aware of the oddities of dying intestate. Read more here:

\section{https://cropwatch.unl.edu/2017/nebraska\%E2\%80\%99s-estate-plan-your-farm}

Parents have also said, "our children get along great right now, I know that this will continue well after my generation is gone." I have observed that oftentimes the parents are the glue that holds the family together. Without that guidance, communication and planning, some families don't get together much after the parents are gone. The lack of contact and communication can lead to disputes in time.

Other parents say, "my business is private, and I am not going to share that with anyone, because no one needs to know." The interesting thing about this assumption is that, in some cases, the parents don't share any information with their children even if there is an estate plan in place. This lack of information for their children can be very upsetting to the family when the plans are revealed after the passing of the older generation. The other hazard of not sharing the information is that the management of the assets is not discussed and the new managers don't have the background or history to properly continue.

Another assumption is, "I know that my children will want to keep this farm in the family. I'm sure that they will keep it even after we are gone." This is a noble assumption. However, there is usually a family member who wants to "cash out." Depending on how the estate plan is written, and this might force all heirs to sell the ground despite the parent's wishes.

"My assets have to be divided equally, that will be the only fair way to do it." This assumption is very common with the older generation. However, when there is one child who has worked with the parents in the operation for decades, is it fair to not reward that child for the sweat equity that he/she has put into the operation?

The last assumption is, "someday (son or daughter), this will all be yours!" This, on the surface, is an honorable statement to make; but if there are more children involved, what is the assurance that the onfarm sibling will be able to continue the farming operation? If the plan is to divide equally, and one of the off-farm siblings wants their portion of the asset in cash, will the on-farm sibling be in the financial position to handle a cash request? 
The main take-home message should be that the parents: 1) have a plan and continue to revise that plan from time to time and 2) be sure to think through the unintended consequences of your plan. Hopefully, some of the common assumptions mentioned here can be put into place so that the family does stay together for decades to come.

This is not an exhaustive list of assumptions that can go awry. It is being presented as a place for family thought and discussion to start. For more information go to: http://agecon.unl.edu/succession. There are other articles and video segments that explain these concepts plus more information.

Allan Vyhnalek is an extension educator in farm/ranch succession and transition in the Department of Agricultural Economics. 